
Canadian Journal of Educational Administration and Policy
Revue canadienne en administration et politique de l'éducation

CJEAP

\title{
Implementation of a Differentiated Instruction Initiative: Perspectives of Leaders
}

\author{
Jessica Whitley, Cheryll Duquette, Suzanne Gooderham, Catherine Elliott, Shari \\ Orders and Amy Klan
}

Number 196, 2021

URI: https://id.erudit.org/iderudit/1078517ar

DOI: https://doi.org/10.7202/1078517ar

See table of contents

Publisher(s)

Department of Educational Administration, University of Saskatchewan

ISSN

1207-7798 (digital)

Explore this journal

Cite this article

Whitley, J., Duquette, C., Gooderham, S., Elliott, C., Orders, S. \& Klan, A. (2021). Implementation of a Differentiated Instruction Initiative: Perspectives of Leaders. Canadian Journal of Educational Administration and Policy / Revue canadienne en administration et politique de l'éducation, (196), 49-64.

https://doi.org/10.7202/1078517ar
Article abstract

Differentiated Instruction (DI) is a framework that supports planning for diversity within K-12 classrooms. Research has grown steadily over the past 15 years that explores DI implementation, as well as beliefs and practices. Literature to date has focused heavily on the experiences of educators, with limited attention given to the role of leadership in implementing DI in schools. The current study explores the perspectives of 19 school and board-level administrators regarding the ways in which a differentiated instruction framework was implemented within their school board as well as facilitators and barriers to the implementation and uptake of the framework. Interviews revealed five themes: a) DI continuum, b) differentiated professional learning supports, c) making space for shared professional learning, d)

align/integrate/embed, and e) multi-level leadership. Our findings reflect a strong belief system of most of the participants with respect to the foundations of DI as well as an understanding of effective approaches to professional learning and school change.
(C) Jessica Whitley, Cheryll Duquette, Suzanne Gooderham, Catherine Elliott, Shari Orders, Amy Klan, 2021
This document is protected by copyright law. Use of the services of Érudit (including reproduction) is subject to its terms and conditions, which can be viewed online.

https://apropos.erudit.org/en/users/policy-on-use/ 


\title{
Implementation of a Differentiated Instruction Initiative: Perspectives of Leaders
}

\author{
Jess Whitley, Cheryll Duquette, Suzanne Gooderham, \\ Catherine Elliott, Shari Orders, \& Amy Klan \\ University of Ottawa
}

\begin{abstract}
Differentiated Instruction (DI) is a framework that supports planning for diversity within K-12 classrooms. Research has grown steadily over the past 15 years that explores DI implementation, as well as beliefs and practices. Literature to date has focused heavily on the experiences of educators, with limited attention given to the role of leadership in implementing DI in schools. The current study explores the perspectives of 19 school and board-level administrators regarding the ways in which a differentiated instruction framework was implemented within their school board as well as facilitators and barriers to the implementation and uptake of the framework. Interviews revealed five themes: a) DI continuum, b) differentiated professional learning supports, c) making space for shared professional learning, d) align/ integrate/embed, and e) multi-level leadership. Our findings reflect a strong belief system of most of the participants with respect to the foundations of DI as well as an understanding of effective approaches to professional learning and school change.
\end{abstract}

Keywords: differentiated instruction, school leadership, professional learning, secondary education, Canadian schools

Differentiated instruction (DI) is a philosophy of teaching and assessment that supports planning for diversity within classrooms. Increasingly, students with a range of needs, strengths, backgrounds, and linguistic profiles are taught in inclusive classrooms alongside same-age peers (Dixon et al., 2014; Subban, 2006). Developing approaches to effectively address and embrace the academic, linguistic, cultural, and social diversity within classes is an ongoing challenge facing educators. To this end, a DI framework has been suggested or required in several countries, including the United States, Canada, Germany, Norway, Hong Kong, and Australia, for elementary, secondary, and even post-secondary settings (e.g., Cameron \& Lindqvist, 2014; Mills et al., 2014; Santangelo \& Tomlinson, 2009; Suprayogi et al., 2017; Wan, 2016). According to Dack (2018),

\section{A teacher in a differentiated classroom recognizes that students enter learning experiences at different starting points and with different backgrounds; thus, they will benefit from multiple options to access information, an array of ways to process information, a variety of outlets to demonstrate learning, and a range of supports. (p. 63)}

This flexibility of content, process, and product and responsiveness to student need is key to DI and reflects the importance of understanding DI as a philosophy rather than a prescribed set of strategies or a packaged program (Tomlinson, 2005). As such, DI is a complex approach, not easily studied or measured.

Literature exploring DI has grown steadily over the past 15 years and has focused on interven- 
Whitley et al.

tion studies in a range of subjects and grades, examinations of teacher beliefs, efficacy and practices, and professional learning for DI; a heavy emphasis on practice-focused articles is also noted (e.g., de Graaf et al., 2019; De Neve \& Devos, 2017; Suprayogi et al., 2017; Valiandes, 2015; van Geel et al., 2019; Whitley et al., 2019). Studies with DI as a focus generally adopt the definition proposed by Tomlinson (2005), where DI is viewed as "a philosophy of teaching purporting that students learn best when their teachers effectively address variance in students' readiness levels, interests, and learning profile preferences" (p. 263). Measures used to capture DI practices and beliefs range from teacher self-report of specific strategies to structured observation guides (Coubergs et al., 2017; van Geel et al., 2019). Findings suggest that teachers' efficacy and use of DI practices vary widely, with a heavy emphasis on differentiation of product, relative to content or process (Moni et al. 2007). Many studies have documented concerns of teachers with respect to their readiness to enact a DI framework as well as varied beliefs about the purpose of differentiating (Dixon et al., 2014; Suprayogi et al., 2017; Wan, 2016; Whitley et al., 2019). A recent meta-analysis exploring the effects of differentiated instruction on student achievement among secondary students found only 12 empirical studies between 2006 and 2016; results demonstrated small to moderate positive effects with effect sizes ranging from .51 to .74 (Smale-Jacobse et al., 2019). Smale-Jocobse et al. identified the range of conceptualizations of DI used in research as a barrier to drawing strong conclusions about its efficacy and suggested more research be conducted in the area (2019).

\section{The Role of School Leadership}

In addition to the influence of teacher beliefs, efficacy and preparedness, implementation of DI and indeed the quality of teaching and learning in general is also impacted by organizational characteristics, including leadership (Leithwood et al., 2020). A review by Bondie and colleagues (2019) of 28 U.S.-based research studies exploring DI teaching practices identified the central role of school principals in "setting the school-wide strategic plan and vision that centered on DI, to providing support for mentors and coaches, to aligning resources for professional development opportunities, such as lesson study and for the creation and sustaining of professional learning communities within the school building" (p. 352).

Research evidence shows that the nature of leadership in place at a school, particularly when combined with a strong school team and a collaborative climate, can have a significant impact on the ability and likelihood of teachers to differentiate in their classrooms (Cobb, 2015; Goddard et al., 2010; Hertberg-Davis \& Brighton, 2006; Puzio et al., 2015; Sider et al., 2017; Smit \& Humpert, 2012). A meta-analysis conducted by Cobb (2015) examined 19 studies conducted over a 10-year period (2001-2011) that explored principal support for inclusion in three domains: inclusive program delivery, staff collaboration, and parental engagement. Within these studies, principals tended to take on roles as visionary, partner, coach, conflict resolver, advocate, interpreter, and organizer. Leadership was categorized as transformative, distributive, or democratic. In most of the studies reviewed, differentiated instruction was identified as a necessary practice for inclusion. Principals often interpreted research related to DI, which could then be used to foster discussion with staff about ways to implement it. Principals also organized resources to support teachers in their professional learning for DI, enacting broader structural supports in terms of class size reductions and delivered consistent messaging reflecting their belief in and promotion of inclusion, with DI at the instructional core.

One relevant study not included in the Cobb (2015) review was conducted by Goddard and colleagues (2010), and it explored the relationship between principal's leadership and the degree to which differentiated instruction was practiced. The sample consisted of 616 Michigan teachers across 80 elementary schools, with an average of 8 teachers per school taking part. Differentiated instruction was assessed on a survey by three items with response options on a five-point scale from strongly agree to strongly disagree. Items focused on the extent to which teachers at the school a) made special efforts to recognize all students' progress, b) provide several different activities in class for students to choose between, and c) offer a wide range of assignments matched to students' needs and skill levels. Principal leadership for instruction was similarly assessed with three items using a 5-point agreement scale: a) helped with instruction, b) empowered them to make decisions that affect teaching and learning, and c) made them feel comfortable discussing instructional issues. A hierarchical linear model was developed to explore the relationship between teacher DI practice and principal leadership. Teacher-level covariates included level of education, gender and minority status, and controls at the school level included SES-related variables and prior student achievement. Results indicated that teachers' use of differenti- 
ated instruction did not vary based on any individual factors, and none of the school-level controls had any association with DI. However, teachers' report of principals' instructional support was a positive, significant predictor of teachers' perceived use of DI in their schools. Limitations of the study include the small number of items on each of the key scales and the reliance on teacher self-reports of practice.

A longitudinal ethnographic exploration of DI implementation was conducted by Hertberg-David and Brighton over three years in three middle schools in the US (2006). Principals and teachers were interviewed multiple times per year, formally and informally by study coaches, who also regularly observed the teachers in their classrooms. Results revealed a range of leadership practices, from strong positive support and participation to complete avoidance of the professional learning initiative and study, and the authors noted that the level of support strongly influenced the implementation of DI by teachers. Principals who were perceived as supportive promoted risk-taking among their staff and were seen as colleagues as well as leaders. Messaging about DI was consistent and positive, planning time for DI was organized and there was regular interaction between the principal and the teachers specifically related to the development of DI practices. Principals often attended PD sessions alongside their teachers. Other principals failed to provide behavioural supports, did not integrate expectations for DI in classroom observations or evaluations, and made it clear that DI was not an instructional priority. As a result, while verbally acknowledging the importance of DI, the principals' behaviour and practice did not reflect an integration of this framework. In one instance, a reluctant principal favoured a different initiative and prioritized it over DI and in another, a leadership style characterized by high control combined with a school climate focused on day-to-day struggle prevented engagement with the professional learning study and with DI broadly. Hertberg-David and Brighton concluded that teachers' willingness and efforts to implement DI "mirrored those of their principals" (p. 99). Furthermore, a focus and vision on the part of school leaders that included a belief in change as well as in DI, alongside emotional and behavioural resources that supported the risks that teachers needed to take to change their practice, was necessary for DI to be implemented.

The findings noted by Hertberg-Davis and Brighton (2006) were echoed in a study by Puzio and colleagues (2015). They highlighted the need for research in principal leadership for differentiated instruction in literacy in their collective case study conducted in three elementary schools over two years. Schools were selected for participation because of the positive gains they experienced in terms of differentiating their literacy practices over two years of a professional learning initiative. In each school, the principal, as well as five teachers $\left(4^{\text {th }}\right.$ and $5^{\text {th }}$ grade) were interviewed a year following the completion of the initiative. Wenger's community of practice theory (1998) was used as a framework to guide questions. Results revealed complex and varied understandings of DI on the part of principals and teachers, with a heavy emphasis on strategies that were the focus of the professional learning strategy (e.g., small groups with leveled texts). Establishing a climate that supported the development of professional capital was identified as necessary support by principals as was the co-construction of alignment around DI through securing resources, providing PD, protecting the literacy block from pull-out services, and conducting required evaluations during the literacy block when DI was expected to take place. In other words, the principals prioritized DI and organized their school processes and structures to visibly and substantially facilitate the development of teacher DI practice. Notably, the principals also leveraged the support of district staff to support teachers and help create a common language and messaging around DI. The authors concluded that the role of the principal as both administrative and learning-centered leaders was critical to the development of DI practices among teachers.

In summary, a leader's view of DI as necessary to inclusive education, messaging about the importance of DI for all students, and supports, including professional learning opportunities, time for shared planning, peer and leader observation increase the likelihood that teachers will shift their practice to reflect a DI framework. The small existing literature base further indicates that in schools where principals take part in PD, including professional learning communities, alongside their staff, DI is more likely to emerge as widespread and consistent (e.g., Hertberg-David \& Brighton, 2006). However, while school-level leadership is often seen as key to DI implementation in schools, little is known about the ways in which this process is viewed from the perspective of principals, particularly those leading secondary schools. The research field exploring DI perceptions and practices is almost entirely dominated by elementary-focused research. As well, literature exploring the perspectives on board-level leaders, who often have responsibilities for supporting school-level leaders in their implementation of DI does not 
yet exist. The current study thus explores the perspectives of school and board-level leaders with the following two research questions in mind: 1) How was the differentiated instruction and assessment framework implemented within the school board?, and 2) What facilitated or constrained the implementation and uptake of the framework? Developing a deeper understanding of the ways in which DI frameworks are realized by leaders within school boards and districts is key to better planning educational change efforts in this area.

\section{Method}

Data from the current study are drawn from a concurrent mixed-methods evaluation conducted in a large east-central Canadian province. The goal of the evaluation was to determine the influence of a multi-year differentiated instruction professional learning initiative on the perceptions and practices of teachers, administrators, and students in grades 7-12. The larger evaluation is not the focus of this paper. A sequential explanatory design (Ivankova et al., 2006) guided the study: the quantitative survey data were first gathered and analyzed, followed by the gathering of qualitative data to assist in interpretation and explanation of the survey results. In the first phase, teachers, school administrators, and board personnel completed a web-based survey, and in the second phase, interviews were conducted in four school boards across the province to further corroborate, contextualize, and expand findings from the surveys. For the current study, interview data gathered from school and board-level administrators were drawn upon to explore perspectives of these educational leaders regarding the ways in which differentiated instruction and assessment framework was implemented within their school board and what facilitated or constrained the implementation and uptake of the framework.

\section{Interviews with School and Board Administrators}

Participant Selection. We initially engaged in the process of identifying school boards that reflected a range of experience and expertise with the DI professional learning initiative, as well as variation with respect to geographic location, school type (grades K-8, 7-12, 9-12), student performance, and achievement outcomes (e.g., provincial standardized exam levels). We approached and applied for ethical approval to conduct research with nine school boards and were ultimately successful in securing participation with four of them.

Following ethical research approval, a student success representative (SSR) from each school board was contacted by the researchers to organize the interviews. SSRs are typically employed at the school board level, although in smaller boards, they may be school-level administrators. Among many other roles and responsibilities, the SSRs provide support for DI-related professional learning. They are, therefore, very knowledgeable about DI practices ongoing at schools within the board, as well as the educators and administrators who are involved in DI implementation. Thus, they were asked by the research team for their advice and assistance in identifying DI-knowledgeable personnel for interviews. Through this process, diverse board and school personnel responsible for managing activities related to DI (i.e., school board curriculum consultants, school superintendents, school administration, resource teachers, SSRs, DI facilitators) were approached and asked if they would take part in the study.

Participants. Individual interviews were conducted with 17 administrators from the four school boards over a 12-week period. Participants included school principals and vice-principals $(n=6$; 3 elementary, 3 secondary) and board personnel $(n=11)$ with positions, sometimes held simultaneously, including student success representative, system principal, secondary program coordinator, education officer, superintendent, and instructional coordinator. Across and within the 4 boards, grades 7 and 8 were typically located in either a K-8 school (elementary) or a 9-12 school (secondary). Reference to an elementary setting in our study refers to a K-8 school structure, but the focus remains throughout the study on students and teachers in grades 7-12.

Interviews. Given the evaluation questions guiding the larger study, interviews focused on factors that enabled or impeded the implementation of DI, professional learning-related activities and resources that were perceived as effective, and the perceived impact of DI on teaching and learning. For example, questions included, "how effective do you think that DI initiatives have been in terms of expanding instructional knowledge/skills of educators" and "what factors do you think are essential for ensuring that DI initiatives are successful?" Interviews were conducted in person at a location chosen by 
the participant. They were recorded on an audio recorder and were approximately 40 minutes in length.

\section{Qualitative Analysis}

Each key informant interview was transcribed verbatim. Following recommendations regarding the trustworthiness of thematic analysis (Nowell et al., 2017), transcripts were e-mailed to the participants for member checking, and a small number of participants provided minor corrections. For the purposes of the present study, a thematic analysis of the transcripts with a specific focus on the research questions of interest, namely the ways in which DI was implemented and the perceived facilitators and constraints influencing this process, was then conducted. The data were analyzed manually to facilitate engagement with the findings (Charmaz, 2000). The five research team members read each interview transcription thoroughly to gain a deep and holistic understanding of the data and individually developed initial codes (Miles \& Huberman, 1994). Next, the team shared codes using a visual process and engaged in a collaborative approach over many hours of organizing and re-organizing codes, often reading aloud quotes from participants that brought these codes to life. Ultimately, this collaborative and dynamic process resulted in the identification of five central themes that emerged from the qualitative interview data, including (a) Differentiated supports, (b) Making space for shared professional learning, (c) Align/integrate/embed, (d) Multi-level leadership, and (e) DI continuum.

\section{Trustworthiness}

Trustworthiness is described as a positive response to the question, "Are these findings sufficiently authentic ... that I may trust myself acting on their implications?" (Lincoln \& Guba, 2000, p. 178). For this study, two methods were used to achieve trustworthiness: credibility and transferability. Credibility refers to the one-to-one correspondence between the researcher's portrayal of the participants' viewpoints and the way those individuals perceive the phenomenon under study (Mertens, 2005). Lincoln and Guba (1985) define credibility as the extent to which the data collected accurately reflect the multiple realities of the phenomenon. The credibility of our data was enhanced by using multiple sources of data from various school boards across the province, which produced diverse perceptions of the implementation of DI. As well, member checks were conducted. Each interview participant was asked to review their transcript to ensure its accuracy, and only a few participants made minor corrections (Denzin, 1978). Transferability refers to the extent to which the findings of a study can be applied to another context. We took care to provide background, context, and sufficient details through thick description (Patton, 1990) in order that the reader may decide if the findings fit their situation.

\section{Findings}

The five themes that emerged from the interviews include the following: (a) Differentiated supports, (b) Making space for shared professional learning, (c) Align/integrate/embed, (d) Multi-level leadership, and (e) DI continuum. Each of these themes will be described, with supporting quotes provided to bring each to life. While described in a linear manner, it is important to note that the themes are closely intertwined and have many points of overlap (see Figure 1). 


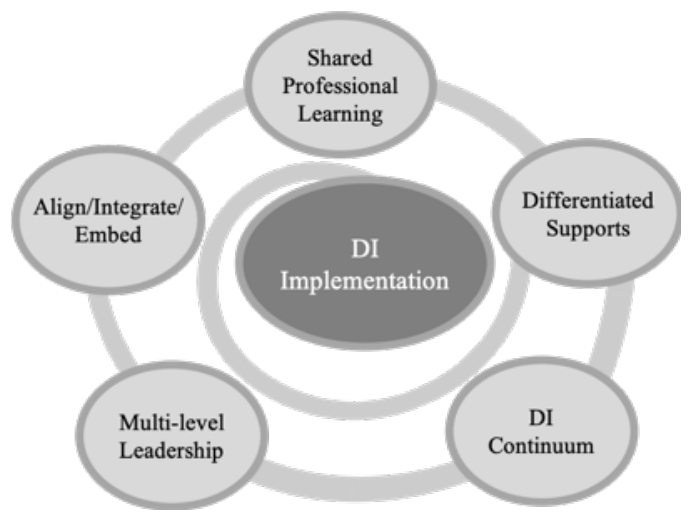

\section{Continuum}

The first theme that emerged from the data captured the continuum of differentiated instruction noted by administrators in terms of depth of understanding, range of beliefs and practices, and the degree of uptake across and within schools they worked in and with. Administrators believed that the implementation of DI depending on a number of variables, including the readiness of the teachers, the resources provided by the school board, the piece-meal vs. school-wide approach adopted, and the grade level or subjects taught.

With respect to teacher response to DI implementation and the professional learning initiative, one administrator described how,

You've got your jetsetters who are there and they just think it's [DI] so great; they want to test it all out, they try it. And then you have the other layer - the pioneers - who are being more thoughtful, but they are still testing out the waters. But then we've got pockets where, "This is the way I've taught, and it's worked for everybody else, and it's going to work for this group".

Other participants similarly described the "movers and the shakers and the cautious ones and the naysayers" as well as the small percentage who need "the extra tender loving care" to identify those teachers more reluctant to embrace what was perceived as a new, risky, and possibly ineffective or shortlived approach to instruction and assessment.

With respect to the continuum of practices, participants described differentiation by product as being the most prevalent, for example, offering choices to students as to what format or modality they want to use to complete an assignment. Differentiation of content or process, for example offering various entry points to a lesson or offering multiple ways of engaging with a concept or activity, was seen as an area of weakness by participants in several boards, resulting in what they perceived as a lack of depth and precision in much of the implementation.

Particular attention in describing the continuum was paid to the secondary school context where participants addressed a perceived tendency or belief of some secondary teachers that curriculum was the driver of planning and instruction rather than student needs. Some participants expressed disappointment and frustration at not being able to shift teachers' beliefs and practices to reflect a greater range and depth of DI.

It is a tough, tough fight to get teachers to realize ... to let go of the curriculum in certain aspects. You've got to keep the integrity of the curriculum; I'm not saying throw it out the window. But I'm saying that the student actually is first, and the curriculum is second.

Within the secondary context, participants also described how pockets of DI implementation emerged within schools as a result of a particular department, typically mathematics or science, engag- 
ing in inquiry as a collaborative team. In these examples, learning about and practicing DI was linked to the introduction of a new curriculum or to a specific subject. A few participants described how "some departments have always done DI" and gave examples of visual arts or technology where they believed DI was inherently or traditionally part of the ways that teachers planned and taught. Individuals teaching those subjects were perceived to be more "ready" to engage with professional learning related to DI implementation.

\section{Differentiated Professional Learning Supports}

Participants described a range of professional learning approaches focused on DI implementation that they either organized, observed, or participated in. This second theme pertaining to differentiated professional learning supports is tightly connected to the first; participants believed that it was necessary to offer a range of opportunities and strategies for teachers to engage with in order to develop their DI practice. A common approach to professional learning was to launch DI implementation with a large board-level workshop and/or to bring in an expert such as Karen Hume or Carol Ann Tomlinson. Following that, most participants described how different forms of collaboration and sharing, among teachers, and particularly with a more knowledgeable coach or learning partner was the most effective way of transforming and sustaining DI practices among teachers. One participant described leading a professional learning session with teachers and the value in having a coach in the room to respond dynamically to the unfolding understandings and misconceptions, in this instance, that a set of strategies constituted DI.

So being able to address well, what was the intention behind that activity, and how did that meet the needs of your learners? And to promote these conversations and get at the fact that if you give everyone the same RAFT, it's not differentiated instruction; they all did exactly same activity. Or if it wasn't based on anything you knew about your students. . So it's funny how things can twist and turn into something that they weren't intended to be. And unless you're there, and with the best intentions in the world - the teachers are trying to do that, it's just that they need the coaching and someone in the room who can question and probe.

Participants mentioned small-scale workshops organized within a department or school, carousels where teachers could share what they were working on and had found effective with teachers from other schools, department heads developing expertise that they could then share with their colleagues, and the local development of personalized DI resources as effective approaches to sharing and implementing DI. One system principal described their perspective that reflected applying principles of differentiation into their professional learning approaches.

You know what, I find that multiple sources are valuable. You need a whole variety. You need the book resources. We all have the Carol Ann Tomlinson books. Because there's one kind of learner that's how they learn, and for another, like me, I like to see it as well... And then obviously in class working alongside teachers, that gives us another way of going deeper into the work. I think you need the range. I think you need more than one way. There isn't one right way.

Beyond the range of types of professional learning for DI, some participants also noted a need to differentiate offerings in terms of teachers' readiness. One board-level student success representative described, "Yes, many layers for the people who are way ahead of the game, the people who are just beginning and for the DI teams in the middle." This participant also identified the need for subject-specific resources and shared planning at the intermediate and secondary levels. For example, some schools and boards focused heavily on DI implementation with a specific focus on math and so described their professional learning through the lens of this subject, with heavy involvement by a core team within a department. The perception shared through the interviews was that for DI to be implemented sustainably in secondary settings, that learning, modeling, and sharing of strategies and resources needed to be centred around a specific subject, curricular area, or course. Again in secondary settings, participants described 
Whitley et al.

department heads and other teacher leaders who served as "DI champions" as being central to the success of DI implementation.

\section{Making Space for Shared Professional Learning}

Key informants from all boards discussed, to varying degrees, the importance of collaborative inquiry and sharing of learnings and resources between teachers as the most effective form of professional learning. While endorsement of collaborative approaches was universal, tensions emerged regarding the ways in which these could be funded and organized. One principal of a K-8 school discussed their strategy.

My big thing - here is a great example - instead of purchasing resources this year, I'm taking that part of my budget and saying to teachers, "go and visit." And don't go by yourself, take someone else so that you can talk about it and then you can share something with the staff. So that's where I'm putting in my resources, so it's coming, but for the teacher to be gone, they have to plan, and it might not be a great time of the week or of the month, but it's coming.

Many participants described the resistance that teachers expressed regarding taking time away from their classrooms to take part in professional learning, particularly the intense and repeated time needed for collaborative inquiry. Some participants described how structural change was necessary in the schools to allow for this time. Other leaders listed innovative solutions they were exploring to support teachers in collaborative sharing. One board-level intermediate/senior principal described how teachers were

....so reluctant to leave their classroom for anything. So I started saying to them, "Okay, you have this budget for release. . . but you don't want to be released. If I sent you to a restaurant and you ate dinner together and then you had a two-hour meeting to share ideas and that sort of thing, would that be better?" And they are much better with that, and it really costs a lot less than release time.

In addition to collaborative inquiry, sharing was also described by participants as opportunities for job-embedded coaching and spending time in each other's classrooms. Again, the barrier of time and a need for innovative ways to reimagine this kind of professional learning within school hours was highlighted many times. According to one vice-principal of a secondary school, "we've got the soft tools and everything, and I think there needs to be a hard change to how to structure schools at 7 to 12 ". This structural barrier was noted particularly at the secondary level as described by a board-level student success representative

...one of key pieces - and I hate to talk about it because it's almost "the thing" that teachers put on the table every time - but it's the timepiece. We're not structured to do the amount of learning that they (teachers) need to do around it [DI]. So the school programs folks will go to the workshops, have the time to do the learning, to get the deep understanding, and then they go out and share it with our staff. But our staff don't have the same time to process, to understand, to practice, to come back to assess where they're at. I don't think it's time; I think it's structures that prohibit that.

\section{Align/Integrate/Embed}

Many key informants described how and when DI was included or aligned within professional learning on specific curricular areas, within new initiatives or policies focused on assessment, within a focus on technology, or aligned with school improvement planning. Some participants described a rationale for these alignment efforts, including attempts to save time and financial resources, increasing acceptance on the part of teachers by appearing less overwhelming, and improving conceptual understanding and increase uptake and implementation. One school board informant described how DI had been embedded into the rollout of the new curriculum in senior secondary math and science. 
So when the new curriculum came out, we slanted it away from the content - although of course, content was a focus - but it was more about delivery. Delivery from the perspective of DI - how you go at this to match all learners and address all learners. And it is evident when we go around through PD and take surveys about assessing for and as learning and flexibility and strategies and instructional practices that the science and math people are further down the road than other subject areas.

At the secondary level, it was seen of paramount importance, as was described previously, to find ways of supporting teachers in understanding and practising DI through specific curriculum areas - by focusing on pedagogy and assessment first, and subject content second. There was a belief shared by some informants that because the curriculum was required, bringing DI into subject areas in secondary schools meant that there would be less resistance and greater sustainability than introducing DI as a policy or initiative.

That is the problem in secondary. It's curriculum fighting students. I'll use the science curriculum rollout as an example. They know curriculum is the most important thing to them, and that's where their passion is - and they have passion for kids too - but they want to cover the curriculum first. And so they have time restraints, right, to do that. So therefore, can you truly differentiate? Well, if I do, a couple of students are going to be way behind and we won't cover all the things. So now it comes down to, do you know your curriculum? Are you trying to teach everything, or just the overalls, or what are you trying to do? So there are a lot of pieces that get in the way.

While integration and embedding of DI were seen by administrators as essential to its sustainability and uptake, there were also instances where DI was addressed narrowly or at a surface level in this pairing. For example, one board-level leader with responsibility for technology described DI as synonymous with the use of various technologies in the classroom, and thus efforts to support the development of teachers' DI practice was solely focused on technological resources and skills. This individual described how they worked with a teacher recently and that "her comment was that you know some of the kids went away from the iPads and started working on paper and some of them wanted to work on computers, and to me that is what DI is, that the kids are making the choice". A further example was noted in one board where there was a strong emphasis on having teachers use a three-part math lesson. The lesson format was situated as the 'vehicle' for DI, and while examples were provided of where DI could be integrated within the various aspects of the lesson format (e.g., multiple access points, grouping, addressing 'visual' learning needs), the descriptions provided by administrators in the board were quite varied in terms of the depth of understanding they reflected. For some, the math lesson was the primary focus, with DI fitting in at certain points, rather than having the math lesson situated within a DI framework. Thus while alignment and embedding DI into new and existing structures and policies was seen as key for professional learning, there were also instances where these efforts resulted in a diluting of DI, potentially leading to misunderstandings on the part of teachers.

\section{Multi-level Leadership}

The key role of leadership at multiple levels was described by the majority of the participants across all boards. From a system perspective, a "filter-down" or "trickle-down" effect as it was referred to in different boards was described where superintendents were supportive of DI, board-level staff worked with principals, who then worked with vice-principals, with subsequent support for department heads, school teams, and individual teachers. At each level of this cascade, and in various activities with the board and schools, including staff meetings, school planning, and professional learning opportunities, the need for consistent messaging regarding DI was highlighted. In many instances, this messaging took the form of pressure and situating DI as a shared priority as described in the following reflection offered by a board-level consultant.

First of all, support from the director and admin councils, superintendents saying, "This is 
important". Probably equal or perhaps even stronger actually, I'll adjust that, is Minister of Ed support, saying, "this is a priority. This needs to be something you build into your work in the different subject areas". And then again, going back to the superintendent support. And then finally, you'll need the department that you work in buying in; your colleagues need to feel this is important. And in this case, we have a system principal who is a department lead, and then there is a group of colleagues who work together. So those different levels of leadership saying, "yes, do it", but also your colleagues saying "this is important to do."

The messaging and leadership required at multiple levels also took the form of specific support for DI implementation, with a focus on instructional leadership on the part of the principal. In the words of one board-level principal,

if our principals don't know what DI is, that it's important in secondary, then there's something wrong [laughs]. And they do know so... I think the principal is a critical driver. So I mentioned that some schools are further down the road because (the principal) took that on. They made it a school-wide focus. So every teacher was in the boat. So you know, "You're going to do it and everybody's going to do it".

A principal of a K-8 school described their focus on being present in classrooms to support DI,

I mean, I'm in the classroom a lot and I'm talking to teachers a lot and if we're doing this then show me the evidence and a lot of it is trying to balance that not putting them under that pressure or making them comfortable and yet this is what we are trying so let me see it so we can talk about it and if I'm not seeing then why not and what can I do to help you.

At the secondary level, discussions of school-level instructional leadership focused on the key role of the department head. One participant who had left their role in a school to take a board-level position described how key having DI experts 'on the ground' was to be able to monitor and shift understanding as part of an organic process.

It's hard to - without the ongoing support, sometimes the misconceptions can develop. So you'll have conversations and you'll work with teachers and you'll think that there is an understanding or that they've got it, and then it will come back around and you'll hear it in a way that's like, "I've been misquoted" [laughs]. If you can't be in the schools - and when I was in my department I was able to be there every day, hearing the conversations, and engaging in that back-and-forth and talking about what might've been a misconception... I wish I could be out there, on the ground with them because that's where I think you have the most impact. So we're trying to do this at a very broad level and it's tough in this role to have the same impact in the classroom that I felt like I was having as a department head. But there's not much you can do about that. That's the reality of it.

\section{Discussion}

In our study, we explored the perceptions of 17 school and board-level administrators regarding the implementation of a differentiated instruction professional learning initiative, with specific attention paid to facilitators and barriers to DI uptake. Participants in our sample include those suggested by SSRs, those leading schools who took part in case studies, and those for whom DI was included in their board-level portfolio. As such, they are not a typical cross-section of individuals in leadership positions within boards but reflect those who are, or who are assumed to be, particularly knowledgeable about DI.

In some instances, participants shared their insights with passion and fervor - DI was not simply an item on their required priority list but a framework that reflected their beliefs about the nature of teaching and learning as inclusive and necessary for all students to be successful. A few expressed frustrations at what they perceived as slow uptake or spread of DI beliefs and practices across schools and the system at large - particularly within secondary settings. For these individuals, the success of DI 
implementation in the board felt personal, and they viewed their leadership role as championing DI and being supportive of teacher learning through organizing and resourcing effective professional learning and development. Other participants spoke to DI from a place of specific interest and expertise, including technology and mathematics, and reflected a more technical perspective on implementation and professional learning - finding more effective ways of improving skill sets among leaders and educators. Previous studies have documented similar approaches that principals have adopted in implementing DI in their schools (e.g., Cobb, 2015; Hertberg-Davis \& Brighton, 2006; Puzio et al., 2015). These studies found that leaders whose efforts reflected a deep understanding of, and commitment to DI, were more effective in their efforts as measured by teacher beliefs and reported practices.

Analyses conducted collaboratively by our research team resulted in the identification of five themes: (a) Differentiated supports, (b) Making space for shared professional learning, (c) Align/integrate/embed, (d) Multi-level leadership, and (e) DI continuum. As mentioned, these themes are closely intertwined in the ways in which they were understood and brought to life by participants. Thus, they will be discussed in an integrated manner.

While considering DI practice from a leadership perspective, participants more often situated the need for learning and development among teachers than leaders. Throughout the themes, there was a recognition that educators and leaders are at different places with respect to beliefs, readiness, practices, and their willingness to take on what is perceived as a new or shifted practice. This finding is well supported in the literature, where the range of perspectives, beliefs, and practices related to DI and its implementation in particular have been well-documented (Moni et al., 2007; Suprayogi et al., 2017; Whitley et al., 2019).

Terms like 'nay-sayers' and 'jet-setters' were used by participants to describe the likelihood of teachers deciding whether or not to engage with DI implementation. In the diffusion of innovation model posited by Rogers (2010), about 15\% of any group of individuals presented with a new idea, behaviour, or product are seen as early adopters or innovators. These individuals are willing to take risks, embrace and believe in a need to change, and they enjoy being leaders. Given the hierarchical structures of school systems, teachers are often faced with implementing initiatives or curricula that are not of their choosing (Oplatka, 2005; Sikes, 1992) - how they respond in the face of required change is one factor of necessary interest to school and board leaders. As stated by Oplatka, "commencing the implementation of an imposed change with committed teachers constitutes an important task for school leaders" (p. 187).

The belief in a continuum of readiness and appetite for innovation expressed by participants was apparent in the range of approaches that were explicitly designed and offered by school and board leaders. Many participants spoke eloquently of the need to reflect the underlying principles of DI in the professional learning opportunities that were provided. This behavioural commitment to an initiative is indicative of a leadership approach that has been shown to result in better integration of DI elements in teacher practice (e.g., Hertberg-Davis \& Brighton, 2006; Puzio et al., 2015). Emerging themes reflected the positive pressure and support described by Fullan (2010), which can be both horizontal, as in the many examples of learning communities, time for shared planning, and in-situ coaching or vertical, as in the examples of common messaging about DI and provision of DI-specific supports at multiple levels. As in the words of one participant, "so those different levels of leadership saying, "yes, do it", but also your colleagues saying "this is important to do."

The horizontal pressure and support described most frequently was the construction and support of collaborative professional learning opportunities. Professional learning approaches that develop collaborative professionalism, where teachers work together to meet common goals, using specific tools or structures in a culture of strong relationships and shared trust, have been shown among the most impactful forms of professional learning and development (Butler \& Schnellert, 2012; Darling-Hammond et al., 2017; Hargreaves \& O'Connor, 2018). With specific attention to DI, many studies have found that teachers perceived benefits from a variety of collaborative approaches to developing DI practices, including coaching and mentorship, book or lesson studies, and professional learning communities (e.g., Bondie et al., 2019).

Time was an oft-cited barrier to DI implementation and was most often defined as necessary to allow for sustained and frequent opportunities for teachers to learn from and with one another. The perceived lack of environmental support necessary to implement DI, including additional time, has been documented in previous research (Goodnough, 2010; Maeng \& Bell, 2015; Moni et al., 2007; Valli \& 
Whitley et al.

Buese, 2007). However, a slightly different narrative emerged among a small number of participants where the emphasis was placed not on time for shared work among individual teachers, but on the organizational shifts necessary for DI to be implemented at the secondary level. Specific mention was made of scheduling and timetabling of the day that prevented engagement in collaborative professional learning, a barrier which has been noted in many other studies (e.g., Admiraal et al., 2016; Hill, 2011).

Vertical pressures and supports were also described as the key role of leadership at multiple levels, including what Hargreaves and Shirley (2018) describe as "from the middle" (p. 3). Leading from the middle (LfM) is described in contrast to either top-down or bottom-up reform efforts, where change is either imposed on systems by a Ministry or Department (top-down) or where it comprises multiple initiatives by individual teachers or schools (bottom-up).

With LfM, schools and school districts do not simply lead "in" the middle by joining up the dots between policies at the top and practice at the bottom. Instead, they lead "from" the middle with shared, professional judgment, collective responsibility for initiating and implementing change, and systemic impact that benefits all students. (p. 3)

The middle is described by Fullan (The Learning Exchange, 2018) as school boards or districts who strengthen their connections with their schools by focusing on shared agendas, connecting laterally across schools, and then leading change vertically, with the Ministry or Department, and with schools. An understanding of the need to connect the DI initiative, imposed by the Ministry, with the priorities, contexts, and activities of schools and teachers was apparent throughout our interviews.

Some participants described explicit planning to enact multi-level leadership, and in other instances, this perspective emerged from examples and stories shared. At the elementary level, evidence of instructional leadership was noted where principals gave examples of ways that they engaged in a shared understanding of DI with educators. At the secondary level, it was more typical to hear about department heads leading a subject-specific DI inquiry, with principals leading implementation through provision of resources such as funding or situating DI as a priority in school-wide messaging. Again the data evidenced repeatedly the key role of department heads in fostering DI practices in secondary settings by leading from the middle. Sharp et al. (2018) state that, "For many schools, fostering more inclusive teaching practices through a focus on embedded differentiated instruction represents a process of significant, long-term organizational learning that requires leadership support at multiple levels" (p. 903). We had insufficient evidence to judge whether distributed leadership (Harris, 2013) was evident throughout systems, but certainly, there was a clear sense of DI being the shared responsibility of individuals working in various roles within the system. There is strong support in the extant research for the positive impact that broad involvement in leadership can have on organizational outcomes and teacher self-efficacy (e.g., Harris, 2013; Harris \& DeFlaminis, 2016). However, some of the examples of the 'spreading' of DI by way of teacher participation in workshops, with the responsibility of engaging colleagues in the concepts and practices just barely learned, raised some flags regarding the common misuse of the premise of shared leadership (Harris \& DeFlaminis, 2016).

One of the unique elements of this study was that it focused on implementation in grades 7-12. The DI research and practice literature is far more heavily weighted in elementary-specific contexts, and secondary teachers have been found to be less likely to integrate DI in their teaching practice (e.g., Pozas et al., 2020; Smit \& Humpert, 2012; Whitley et al., 2019). In our study, the principals who spoke about instructional leadership in implementing DI were in elementary schools that included grade $7 \mathrm{~s}$ and 8s. The "curriculum fighting students" perspective of secondary contexts has been noted in much of the inclusive education literature and in more limited DI-specific literature (De Vroey et al., 2016; Pearce et al., 2010; Whitley et al., 2019). According to De Vroey and colleagues (2016), "secondary schools have retained subject-based structures, assigning expert teachers to many classes, which functions as a barrier for teachers to know students' needs or to build a school for all" (p. 111). Organizational challenges, as well as a climate that can situate priorities on subject mastery, are often described as barriers to inclusive education and, specifically, to the implementation of DI in secondary schools. Our study shows that these considerations are understood by leaders. In particular, many administrators pointed to the need for subject-specific DI resources and the perceived success of departmentally situated professional learning. 


\section{Limitations, future research and recommendations}

There are several limitations of our study to consider. The first is that our participants reflected a group of school- and board-level administrators who were identified as particularly knowledgeable about DI. As such, they reflect an interested and engaged group who are likely far more aware of DI implementation in their board, and of DI in general, than leaders in general. Future research that explores the views of a more diverse group of leaders at multiple levels within the system would add to this body of literature.

The field of DI and inclusive education broadly would also benefit from more research to identify the ways in which leaders can and do guide and influence the implementation of DI. DI is unique as an initiative to implement in that it is not specific to a subject but requires a set of beliefs about teaching/ learning/students/schools as well as specific skills in pedagogy and assessment. The scant research exploring leadership for inclusive education has been noted elsewhere (e.g., Sider et al., 2017); this gap is far greater when considering the role of secondary school leadership. Given our findings, developing a greater understanding of the roles of school-based leaders such as department heads and teacher leaders who are charged with sharing knowledge among their colleagues is needed; this recommendation has been noted elsewhere as well (e.g., Admiraal et al., 2019). Individuals in these roles are not always considered 'leaders' in the research literature but they are positioned within school change, and by our participants, as key to reform implementation.

Several recommendations emerge from our findings. First, considering the unique context of secondary schools is essential in implementing DI initiatives. Our participants noted the barriers presented by a lack of organized, regular, shared time for professional learning. This is a frequent concern for teachers across grade levels, but the structure and timetabling unique to secondary schools, as well as the tensions between a deep focus on subjects alongside an equal emphasis on student needs, requires a differentiated approach. Some examples of creating conditions to allow for team teaching, reductions in total teaching time, planning schedules to allow having blocks of time shared by teachers, starting a school day later one day per week are examples of creative solutions seen in current and recommended practices (Admiraal et al., 2016; Puzio et al., 2015). Our findings also speak to the need to adopt a broader view of leadership in planning the implementation of DI initiatives, including recognizing the important role played by teacher-leaders and department heads in secondary schools as translators, facilitators, mentors, and coaches alongside administrators engaged in leading from the middle.

\section{References}

Admiraal, W., Kruiter, J., Lockhorst, D., Schenke, W., Sligte, H., Smit, B., Tigelaar, D., \& de Wit, W. (2016). Affordances of teacher professional learning in secondary schools. Studies in Continuing Education, 38(3), 281-298. https://doi.org/10.1080/0158037X.2015.1114469

Admiraal, W., Schenke, W., De Jong, L., Emmelot, Y., \& Sligte, H. (2019). Schools as professional learning communities: What can schools do to support professional development of their teachers? Professional Development in Education, 1-15. https://doi.org $/ 10.1080 / 19415257.2019 .1665573$

Bondie, R. S., Dahnke, C., \& Zusho, A. (2019). How does changing “one-size-fits-all” to differentiated instruction affect teaching? Review of Research in Education, 43(1), 336-362. https://doi.org/10.3102\%2F0091732X18821130

Butler, D. L., \& Schnellert, L. (2012). Collaborative inquiry in teacher professional development. Teaching and Teacher Education, 28(8), 1206-1220. https://doi.org/10.1016/j. tate.2012.07.009

Cameron, D. L., \& Lindqvist, G. (2014). School district administrators' perspectives on the professional activities and influence of special educators in Norway and Sweden. International Journal of Inclusive Education, 18(7), 669-685. https://oi.org/10.1080/13603 116.2013.803609

Charmaz, C. (2000). Grounded theory objectivist and constructivist methods. In N. K. Denzin \& Y. S. Lincoln (Eds.), Handbook of qualitative research (2nd ed., pp. 509-536). Sage.

Cobb, C. (2015). Principals play many parts: A review of the research on school principals as special education leaders 2001-2011. International Journal of Inclusive Education, 19(3), 213-234. https://doi.org/10.1080/13603116.2014.916354 
Whitley et al.

Coubergs, C., Struyven, K., Vanthournout, G., \& Engels, N. (2017). Measuring teachers' perceptions about differentiated instruction: The DI-Quest instrument and model. Studies in Educational Evaluation, 53, 41-54. https://doi.org/10.1016/j.stueduc.2017.02.004

Dack, H. (2018). Structuring teacher candidate learning about differentiated instruction through coursework. Teaching and Teacher Education, 69, 62-74. https://oi.org/10.1016/j. tate.2017.09.017

Darling-Hammond, L., Hyler, M. E., Gardner, M. (2017). Effective teacher professional development. Learning Policy Institute.

Denzin, N. (1978). Sociological methods. McGraw-Hill.

De Vroey, A., Struyf, E., \& Petry, K. (2016). Secondary schools included: A literature review. International Journal of Inclusive Education, 20(2), 109-135. https://doi.org/10.1080/136031 16.2015.1075609

Dixon, F. A., Yssel, N., McConnell, J. M., \& Hardin, T. (2014). Differentiated instruction, professional development, and teacher efficacy. Journal for the Education of the Gifted, 37(2), 111-127. https://doi.org/10.1177\%2F0162353214529042

De Neve, D., \& Devos, G. (2017). How do professional learning communities aid and hamper professional learning of beginning teachers related to differentiated instruction? Teachers and Teaching, 23(3), 262-283. https://doi.org/10.1080/13540602.2016.1206524

de Graaf, A., Westbroek, H., \& Janssen, F. (2019). A practical approach to differentiated instruction: How biology teachers redesigned their genetics and ecology lessons. Journal of Science Teacher Education, 30(1), 6-23. https://doi.org/10.1080/1046560X.2018.1523646

Fullan, M. (2010). Positive pressure. In A. Hargreaves, A. Lieberman, M. Fullan, \& D. Hopkins (Eds.), Second international handbook of educational change (pp. 119-130). Springer.

Goddard, Y. L., Neumerski, C. M., Goddard, R. D., Salloum, S. J., \& Berebitsky, D. (2010). A multilevel exploratory study of the relationship between teachers' perceptions of principals' instructional support and group norms for instruction in elementary schools. The Elementary School Journal, 111(2), 336-357. https://doi.org/10.1086/656303

Goodnough, K. (2010). Investigating pre-service science teachers' developing professional knowledge through the lens of differentiated instruction. Research in Science Education, 40, 239-265. https://doi.org/10.1007/s11165-009-9120-6

Hargreaves, A., \& O'Connor, M. T. (2018). Collaborative professionalism: When teaching together means learning for all. Corwin Press.

Hargreaves, A., \& Shirley, D. (2018). Executive summary. Leading from the middle: Spreading learning, well-being, and identity across Ontario. http://ccsli.ca/downloads/2018-Leading _ From_the_Middle_Summary_Final-EN.pdf

Harris, A. (2013). Distributed leadership: Friend or foe?. Educational Management Administration \& Leadership, 41(5), 545-554. https://doi.org/10.1177\%2F1741143213497635

Harris, A., \& DeFlaminis, J. (2016). Distributed leadership in practice: Evidence, misconceptions and possibilities. Management in Education, 30(4), 141-146. https://doi. org $/ 10.1177 \% 2$ F0892020616656734

Hertberg-Davis, H. L., \& Brighton, C. M. (2006). Support and sabotage principals' influence on middle school teachers' responses to differentiation. Journal of Secondary Gifted Education, 17(2), 90-102. https://doi.org/10.4219/jsge-2006-685

Hill, M. F. (2011). 'Getting traction': Enablers and barriers to implementing assessment for learning in secondary schools. Assessment in Education: Principles, Policy \& Practice, 18(4), 347-364. https://doi.org/10.1080/0969594X.2011.600247

Ivankova, N. V., Creswell, J. W., \& Stick, S. L. (2006). Using mixed-methods sequential explanatory design: From theory to practice. Field methods, 18(1), 3-20. https://doi. org $/ 10.1177 \% 2 \mathrm{~F} 1525822 \mathrm{X} 05282260$

Leithwood, K., Harris, A., \& Hopkins, D. (2020). Seven strong claims about successful school leadership revisited. School Leadership \& Management, 40(1), 5-22. https://doi.org/10.1080/ 13632434.2019.1596077 
Lincoln, Y. S., \& Guba, E. G. (1985). Naturalistic inquiry. Sage.

Lincoln, Y. S., \& Guba, E. G. (2000). Paradigmatic controversies, contradictions, and emerging confluences. In N. Denzin \& Y. S. Lincoln (Eds.), The handbook of qualitative research (2nd ed., pp. 166-188). Sage.

Maeng, J. L., \& Bell, R. L. (2015). Differentiating science instruction: Secondary science teachers' practices. International Journal of Science Education, 37(13), 2065-2090. https:// doi.org/10.1080/09500693.2015.1064553

Mertens, D. (2005). Research and evaluation in education and psychology (2nd ed.). Sage.

Miles, M., \& Huberman, M. (1994). Qualitative data analysis: A sourcebook of new methods (2nd ed.). Sage.

Mills, M., Monk, S., Keddie, A., Renshaw, P., Christie, P., Geelan, D., \& Gowlett, C. (2014). Differentiated learning: From policy to classroom. Oxford Review of Education, 40(3), 331-348. https://doi.org/10.1080/03054985.2014.911725

Moni, K. B., Jobling, A., van Kraayenoord, C. E., Elkins, J., Miller, R., \& Koppenhaver, D. (2007). Teachers' knowledge, attitudes and the implementation of practices around the teaching of writing in inclusive middle years' classrooms: No quick fix. Educational and Child Psychology, 24(3), 18-36.

Nowell, L. S., Norris, J. M., White, D. E., \& Moules, N. J. (2017). Thematic analysis: Striving to meet the trustworthiness criteria. International Journal of Qualitative Methods, 16(1), 1609406917733847. https://doi.org/10.1177\%2F1609406917733847

Oplatka, I. (2005). Imposed school change and women teachers' self-renewal: a new insight on successful implementation of changes in schools. School Leadership \& Management, 25(2), 171-190. https://doi.org/10.1080/13632430500036165

Patton, M. Q. (1990). Qualitative research and evaluation methods (3rd ed.). Sage.

Pearce, M., Gray, J., \& Campbell-Evans, G. (2010). Challenges of the secondary school context for inclusive teaching. Issues in Educational Research, 20(3), 294-313.

Pozas, M., Letzel, V., \& Schneider, C. (2020). Teachers and differentiated instruction: Exploring differentiation practices to address student diversity. Journal of Research in Special Educational Needs, 20(3), 217-230. https://doi.org/10.1111/1471-3802.12481

Puzio, K., Newcomer, S. N., \& Goff, P. (2015). Supporting literacy differentiation: The principal's role in a community of practice. Literacy Research and Instruction, 54(2), 135-162. https:// doi.org/10.1080/19388071.2014.997944

Rogers, E. M. (2010). Diffusion of innovations. Simon and Schuster.

Santangelo, T., \& Tomlinson, C. A. (2009). The application of differentiated instruction in postsecondary environments: Benefits, challenges, and future directions. International Journal of Teaching and Learning in Higher Education, 20(3), 307-323.

Sharp, K., Jarvis, J. M., \& McMillan, J. M. (2020). Leadership for differentiated instruction: Teachers' engagement with on-site professional learning at an Australian secondary school. International Journal of Inclusive Education, 24(8), 901-920. https://doi.org/10.1080/136031 16.2018.1492639

Sider, S., Maich, K., \& Morvan, J. (2017). School principals and students with special education needs: Leading inclusive schools. Canadian Journal of Education/Revue canadienne de l'éducation, 40(2), 1-31.

Sikes, P. J. (1992). Imposed change and the experienced teacher. In M. Fullan \& A. Hargreaves (Eds.), Teacher development and educational change. The Falmer Press.

Smale-Jacobse, A. E., Meijer, A., Helms-Lorenz, M., \& Maulana, R. (2019). Differentiated instruction in secondary education: A systematic review of research evidence. Frontiers in Psychology, 10, 2366. https://doi.org/10.3389/fpsyg.2019.02366

Smit, R., \& Humpert, W. (2012). Differentiated instruction in small schools. Teaching and Teacher Education, 28(8), 1152-1162. https://doi.org/10.1016/j.tate.2012.07.003

Subban, P. (2006). Differentiated instruction: A research basis. International Education Journal, 7(7), 935-947. 
Whitley et al.

Suprayogi, M. N., Valcke, M., \& Godwin, R. (2017). Teachers and their implementation of differentiated instruction in the classroom. Teaching and Teacher Education, 67, 291-301. https://doi.org/10.1016/j.tate.2017.06.020

The Learning Exchange. (2018). Michael Fullan: Charting the course for change. Leaders in educational thought: Ways of change. https://thelearningexchange.ca/projects/leaders-educational-thought-ways-change-video/

Tomlinson, C. A. (2005). Grading and differentiation: Paradox or good practice? Theory into Practice, 44(3), 262-269. https://doi.org/10.1207/s15430421tip4403_11

Valiandes, S. (2015). Evaluating the impact of differentiated instruction on literacy and reading in mixed ability classrooms: Quality and equity dimensions of education effectiveness.

Studies in Educational Evaluation, 45, 17-26. https://doi.org/10.1016/j.stueduc.2015.02.005

Valli, L., \& Buese, D. (2007). The changing roles of teachers in an era of high-stakes accountability. American Educational Research Journal, 44(3), 519 -558. https://doi. org $/ 10.3102 \% 2 \mathrm{~F} 0002831207306859$

van Geel, M., Keuning, T., Frèrejean, J., Dolmans, D., van Merriënboer, J., \& Visscher, A. J. (2019). Capturing the complexity of differentiated instruction. School Effectiveness and School Improvement, 30(1), 51-67. https://doi.org/10.1080/09243453.2018.1539013

Wan, S. W. Y. (2016). Differentiated instruction: Hong Kong prospective teachers' teaching efficacy and beliefs. Teachers and Teaching, 22(2), 148-176. https://doi.org/10.1080/1354060 2.2015.1055435

Wenger, E. (1998). Communities of practice: Learning as a social system. Systems Thinker, 9(5), 2-3.

Whitley, J., Gooderham, S., Duquette, C., Orders, S., \& Cousins, J. B. (2019). Implementing differentiated instruction: A mixed-methods exploration of teacher beliefs and practices. Teachers and Teaching, 25(8), 1043-1061. 